

\section{Reinvigorating Film Studies: An Immodest Proposal}

\section{Murat Akser}

It has been almost fifty years when film studies have entered into university curricula. The first courses were available under English departments and later film studies began operating as individual departments. Scholarly journals followed suit. The publication of Screen and Cinema Journal were later followed by Quarterly Review of Film and Video, Cineaction and others. For each period, there was a major theoretical debate, fuelled by the inclinations of the editors and contributors. The semiotic turn, feminist movement, apparatus theory and later race and identity politics became staple topics for film studies journals. For a time auteur director studies and national cinema approches were favored and then historical, in-depth archival film analyses dominated.

Why need another journal then? For starters because there is a lot of uncovered field and neglected, even dismissed topics. Another issue is the virtual exclusion of non-Anglophone/non-European cinemas and their scholars from English language scholarly film studies journals.

CINEJ Cinema Journal is a peer-reviewed semiannually published international cinema Journal. It is published by the University Library System, University of Pittsburgh and is co-sponsored by the University of Pittsburgh Press. CINEJ Cinema Journal is committed to publishing fresh and original research in the fields of film and media studies. Areas include but are not limited to:

- Film historiography and methodology

- Film festival studies

- Documentary and nonfiction cinema

- Transnational/global cinema(s)

- Television studies

- Cinema and new/digital media

- Production studies 
The above topics are just the suggested areas where the journal will go in depth in coming issues. There is already an interest in film festival studies under Dina Iordonova (2009), Richard Porton (2009) and at SCMS with scholars like Kay Armitage (2003) and Liz Zsach. Transnational and global cinemas were again studied by Robert Stam, Ella Shohat (2003) and Thomas Elsaesser (2005) along with hard work of Iordonova (2008), Bayrakdar (2009) and Downing (1996). Documentary film has been under new discussion by Louise Spence (2011), production studies is taken to new heights by people like Janet Wasko (2008) and film theory and criticism is tested year after year by the innovative works of Dudley Andrew (2010), Murray Pomerance (2008) and Barry Keith Grant (2010). The future is ripe for fruitful writing on diverse but unattended areas of research.

There is a history to this radical thinking about film scholarship too. As inspired by people around Cineaction, a Toronto-based film journal of radical film criticism, I am inebted to Robin Wood (2002), Scott Forsyth, Janine Marchessault, and Richard Lippe. Other Canadian scholars Seth Feldman (2002), Ewan Cameron and Brenda Longfellow also shaped my idea of perfection through variety when it comes to editing a scholarly piece. The creation of this journal owes a lot to many people. I would like to cite Vedat Akman and Serhan Oskay for coming up with innovative ideas on establishing an alternative film journal and inviting me to edit it. They run a sister journal EMAJ, a business journal on emerging markets also published by Pittsburgh University Press. Vanessa Gabler on the Pittsburgh end created wonders to assist us in the creation of this journal. I wouls also like to thank all of the editorial team and advisory board who spare time out of their busy schedules for this new journal.

This first issue has four original articles in addition to this introduction. Ann McMurray's is analysis of perception of Abbas Kiarostami's Certified Copy from Baudrialarian perspective and how the novel ways of pulling the audience into the cinematic narrative are initiated. Next is Melissa Meade looking at three Colombian films where she initates a thematic/stylistic analysis of these films with viloence in the foreground. Vedat Akman article is on short films and how they are identified in Crossroads intercultrual and international short film festival that had thousands of short films screened in the last eight years. Finally Basak Demiray's comparative analysis of filmwithin-film is a comparative look at filmaking pracitices in Italian and Turkish contexts. Cinema Paradiso and three Turkish films are compared most notably the wonderous filmmaker Ahmet Ulucay's work.

The first issue is a beginning and like all beginnings it is the first step of a long journey. I hope we achive our aims of perfection through variety in the coming issues. The best is yet to come! 


\section{REFERENCES}

Andrew, D. (2010) What cinema is! London: Wiley-Blackwell.

Armitage, K. (2003). The girl from god's country: Nell Shipman and the silent cinema, Toronto: University of Toronto Press.

Bayrakdar, D. ed. (2009). Cinema and Politics, London: Cambridge Scholars Press.

Downing, John D.H. (1996). Internationalizing media theory, London: Sage.

Elsaesser, T. (2005) European cinema: face to face with Holywood, Amsterdam: Amsterdam University Press.

Feldman, S. (2002). Allan King: filmmaker, Indiana University Press.

Grant, B.K. (2010). Shadows of doubt: negotiations of masculinity in american genre films, Detroit: Wayne State University Press.

Iordonova, D. (2009) Film festival yearbook, St. Andrews University Press.

Iordonova, D. (2003). Cinema of the other europe, London: Wallflower Press.

Pomerance, M. (2008). The horse who drank the sky: film experience beyond narrative and theory, New Jersey: Rutgers University Press.

Porton, R. Dekalog 3:on film festivals, London: Wallflower Press.

Shohat, E. and R. Stam. (2003). Multiculturalism, postcoloniality, and transnational media, New Jersey: Rutgers University Press.

Spence, L. And V. Navarro (2011) Crafting truth: documentary form and meaning, New Jersey: Rutgers University Press.

Wasko, J. and M. Erickson eds. (2008). Cross-border cultural production: economic runaway or globalization?, Cambria Press.

Wood, R. (2002) American cinema from vietnam to Reagan and beyond..., New York: Columbia Universiy Press. 